\title{
P-17
}

\section{Assessment of Irrigation Scheduling in Pelwatte Seed Cane Plantation}

\author{
Mendis A.P.S., Jayasinghe G.Y. * and Jayasanka J. \\ Department of Agriculture Engineering, Faculty of Agriculture, University of Ruhuna, \\ Kamburupitiya, Sri Lanka \\ victorlion3000@gmail.com*
}

\begin{abstract}
Sugarcane (Saccharum officinarum L) is mainly grown in the dry zone of Sri Lanka where the major soil group is well drained Reddish Brown Earth. Pelwatte Sugar Industries Limited cultivates more than 4,000 hectare of sugarcane. Uneven and unpredictable rainfall in the dry zone makes it necessary of the irrigation. This research project was conducted to develop an alternative system to overcome weaknesses of the existing irrigation system. Irrigation interval, irrigation time and net irrigation depth was measured via a number of equations, which used in irrigation scheduling. Distribution uniformity was found by three can tests for existing and suggested spacing and those tests were helpful to find irrigation rate. Other miscellaneous practices are equal for both suggested and existing systems. Irrigation interval of the existing system is around 10 to 14 days. Irrigation time is 3 hours. Irrigation rate of the system is $6.30 \mathrm{~mm} \mathrm{hr}^{-1}$. Net irrigation depth is $18.7 \mathrm{~mm}$; hence water requirement per hectare is $186.75 \mathrm{~m}^{3}$. Spacing used in existing sprinkler system is $18 \mathrm{~m} \times 18 \mathrm{~m}$ and average distribution uniformity is $55.71 \%$. Area covered in a day is 1.7 hectare. Fuel cost per hectare is Rs. 3,395.00. Suggested irrigation interval of the study was 14 days. Net irrigation depth was $33.2 \mathrm{~mm}$. Two spacing systems were suggested, $18 \mathrm{~m} \times 12 \mathrm{~m}$ spacing system and $12 \mathrm{~m} \times$ $12 \mathrm{~m}$ system. Distribution uniformity and discharge rate increment of the two systems was statistically significant over existing system. Their values and corresponding $p$ values are $70.8 \%, 0.026$ and $10.427 \mathrm{~mm} \mathrm{hr}^{-1}, 0.002$ for $18 \mathrm{~m} \times 12 \mathrm{~m}$ system and $83.5 \%, 0.007$ and 16.6 $\mathrm{mm} \mathrm{hr}{ }^{-1}, 0.014$ for $12 \mathrm{~m} \times 12 \mathrm{~m}$ system respectively. Irrigation time, area covered within a day, water requirement per hectare and fuel cost per hectare for $18 \mathrm{~m} \times 12 \mathrm{~m}$ system are consecutively 3 hours and 11 minutes, 1.2 hectare, $332.49 \mathrm{~m}^{3}$ and Rs. $6,034.00$ and for $12 \mathrm{~m}$ $\times 12 \mathrm{~m}$ system are 2 hours, 1.1 hectare, $332.49 \mathrm{~m}^{3}$ and Rs. 5,060.00. It can be concluded that both suggested systems were improved distribution uniformity and irrigation rate significantly. Moreover, net irrigation depth of the new system was almost twice compared to existing system, which explains the inadequate wetting of the existing system. $12 \mathrm{~m} \times 12 \mathrm{~m}$ system is superior over both $18 \mathrm{~m} \times 12 \mathrm{~m}$ spacing and existing system.
\end{abstract}

Keywords: Irrigation, Irrigation interval, Sugarcane, Seed cane, Uniformity distribution 